Article

\title{
Conceptualising Tourism Sustainability and Operationalising Its Assessment: Evidence from a Mediterranean Community of Projects
}

\author{
Spyros Niavis ${ }^{1, *(D)}$, Theodora Papatheochari ${ }^{1}$, Yannis Psycharis ${ }^{1}$, Josep Rodriguez ${ }^{2}$, \\ Xavier Font $^{2}$ (I) and Anna Martinez Codina ${ }^{2}$ \\ 1 Department of Economic and Regional Development, Panteion University of Social and Political Sciences, \\ 17671 Athens, Greece \\ 2 Tourism Technical Office, Barcelona Provincial Council, 08028 Barcelona, Spain \\ * Correspondence: niavisspiros@gmail.com
}

Received: 22 June 2019; Accepted: 25 July 2019; Published: 26 July 2019

check for updates

\begin{abstract}
Sustainable tourism development is considered an essential challenge for improving resource management in coastal and maritime areas. In this context, various initiatives have been developed for facilitating the assessment and monitoring of tourism sustainability. Nevertheless, the perception of sustainability varies across different tourism stakeholders, since they approach tourism development under different perspectives while the issue of data availability has been a great barrier in measuring sustainability. The present paper examines the perceptions of sustainability observed over a Community of projects with the common aim of enhancing coastal and maritime tourism sustainability at the Mediterranean. Based on surveys, the Community of projects conceptualizes sustainability, reveals their own strategies in operationalizing sustainability assessment and evaluates the usefulness and the main gaps of various sustainability assessment toolkits. The findings of the study signify that tourism sustainability is a broad concept allowing for different interpretations. The assessment of sustainability seems to be affected by the perception and weight attributed to the economic, social, environmental, and governance pillar of sustainability by each project. Finally, the applicability of international assessment toolkits could be questioned as these do not reflect the objectives of the projects and tailored made approaches are considered as essential for operationalizing sustainability assessments.
\end{abstract}

Keywords: tourism sustainability assessment; perceived ease of use; perceived usefulness; Mediterranean; indicators; Destination Management Organisations

\section{Introduction}

Tourism is increasingly acknowledged in policy agendas for its role in fostering economic growth, generating employment and its potential in valorising cultural and natural assets [1]. Its contribution can also be recognized in an international level with the UN General Assembly having adopted several agreements acknowledging the role of tourism in sustainable development, including the 2030 Agenda and its Sustainable Development Goals (SDGs) [2].

Despite the importance of the tourism sector for the national and local economies, tourism development could jeopardize social welfare and economic growth when it is not based on the principles of sustainability $[3,4]$. Therefore, sustainability acquires a notable importance for tourism planning and management practices. The general principle of sustainability which calls for the adoption of a tourism development pattern, which can bring the most of socioeconomic benefits by preserving, at the highest possible way, the cultural and physical environment of a destination, 
could be regarded as a globally accepted rationale among tourism academics and practitioners [5]. Nevertheless, such a general approach allows for various interpretations and, thus, there is not a full consensus yet regarding the exact definition of tourism sustainability [6]. This is because sustainability is a rather complex concept shaped by various and, often, opposite perspectives of the involved actors representing various political, economic, environmental, and ethical issues [7].

The complex nature of sustainability, as a concept, constitutes its measurement a difficult task. This is because sustainability, as a strategic target, allows for various approaches when it comes to its operationalization through plans, management practices, and projects on different types of tourism and at various spatial scales [8,9]. The challenges of adjusting tourism sustainability indicators on the particular challenges of the destinations have been extensively analysed in the papers of $[10,11]$. In addition, the long-standing debate of measuring sustainability has led to the organization of the Working Group on Measuring Sustainable Tourism, held under the UNWTO, in order to operationalize the International Recommendations for Tourism Statistics which have been produced since 2008 [12]. These actions are quite indicative of the complexity of tourism sustainability evaluation.

The major work, carried out by the UNWTO, towards the measurement of tourism sustainability is complemented by other Tourism Sustainability Assessment Initiatives (TSAIs), which are being presented in Table 1. As can be seen from Table 1, there are quite a lot of initiatives which differentiate, for example, in terms of their target groups, the criteria used, their spatial orientation, and their outputs. Most of the initiatives target at improving the capacity of policy makers. Nevertheless, GSTC [13] provides a set of indicators for private actors, whilst ECST [14] provides a set of principles in order for Protected Areas Managers to be able to assess their sustainability. In addition, a great divergence is observed over the sets of criteria proposed by each initiative and their approach towards the sustainability concept. Therefore, GSTC [13] and ETIS [15] are mostly adjusted on the three pillars of sustainability (economic, socio-cultural, and environmental), UNWTO [16-18] initiatives focus mainly on the economic contribution of tourism, TOUERM [19] deals mostly with environmental issues, and OECD [20] guidelines promote competitiveness as a means of sustainability, whilst NECSTouR [21] adopts a broader approach of sustainability as it adjusts its indicators to the targets of the EU Agenda for Sustainable and Competitive Tourism [22].

Most of the proposed indicators are focusing on the local scale, covering the measurement of tourism sustainability at the local destination level. Nevertheless, the indicators proposed by UNWTO [16] and OECD [20] are referring to the national spatial scale providing some recommendations for adapting them to lower spatial contexts, whilst in a number of the observatories of UNWTO (INSTO) [18], there are measurements of sustainability which are adapted to both the local and national scale. Additionally, a division among the initiatives could be established on the basis of their outputs and whether they are simple recommendations for measuring tourism sustainability or they are also accompanied with relevant information that could be useful for the users. It should be noted that most of the initiatives produce recommendations on the use of indicators while data and information can be extracted in the case of UNWTO [16], TOUERM [19], and INSTO [18]. 
Table 1. The structural characteristics of the main Tourism Sustainability Assessment Initiatives (TSAI).

\begin{tabular}{|c|c|c|c|c|}
\hline TSAI & Target Groups & Criteria & Spatial Scale & Output \\
\hline $\begin{array}{c}\text { Global Sustainable Tourism Council—GSTC } \\
{[13]}\end{array}$ & $\begin{array}{l}\text { Two sets of Indicators Targeting } \\
\text { at Policy Makers and Private } \\
\text { Actors }\end{array}$ & $\begin{array}{l}\text { (1) Sustainable management } \\
\text { (2) Socioeconomic impacts } \\
\text { (3) Cultural impacts } \\
\text { (4) Environmental impacts }\end{array}$ & Local & Indicators \\
\hline $\begin{array}{l}\text { United Nations World Tourism } \\
\text { Organisation-UNWTO [16] }\end{array}$ & Policy Makers & The most recent revision includes only indicators for Economy and Employment & National & Data and Indicators \\
\hline Tourism Satellite Account-TSA [17] & Policy Makers & $\begin{array}{l}\text { (1) Visitors consumption } \\
\text { (2) Production of goods and services } \\
\text { (3) International trade of goods and services } \\
\text { (4) Number of jobs }\end{array}$ & National & Data and Indicators \\
\hline $\begin{array}{l}\text { International Recommendations for Tourism } \\
\text { Statistics_-IRTS [18] }\end{array}$ & Policy Makers & $\begin{array}{l}\text { (1) Measuring Flows of Visitors } \\
\text { (2) Measuring the characteristics of visitors and tourism trips } \\
\text { (3) Measuring Tourism Expenditure } \\
\text { (4) Measuring the supply of services of tourism industries } \\
\text { (5) Measuring Employment }\end{array}$ & National & Indicators \\
\hline $\begin{array}{c}\text { International Network of Sustainable Tourism } \\
\text { Observatories (INSTO) [23] }\end{array}$ & Policy Makers & Various Criteria According to the Observatory & National/Local & Data \\
\hline $\begin{array}{c}\text { Organisation for Economic Co-operation and } \\
\text { Development-OECD [20] }\end{array}$ & Policy Makers & $\begin{array}{l}\text { (1) Tourism performance and Impacts } \\
\text { (2) Ability of a destination to deliver quality and competitive tourism services } \\
\text { (3) Attractiveness of a destination } \\
\text { (4) Policy responses and economic opportunities }\end{array}$ & National & Indicators \\
\hline $\begin{array}{c}\text { European Tourism Indicators System—ETIS } \\
\text { [15] }\end{array}$ & Policy Makers & $\begin{array}{l}\text { (1) Destination management } \\
\text { (2) Social and Cultural Impact } \\
\text { (3) Environmental Impact }\end{array}$ & Local & Indicators \\
\hline $\begin{array}{l}\text { Tourism and Environment Reporting } \\
\text { Mechanism-TOUERM [19] }\end{array}$ & Policy Makers & $\begin{array}{l}\text { (1) Driver indicators } \\
\text { (2) Pressure indicators } \\
\text { (3) State indicators } \\
\text { (4) Impact indicators } \\
\text { (5) Response indicators }\end{array}$ & Various & Data/Indicators \\
\hline $\begin{array}{l}\text { Network of European Regions for Sustainable } \\
\text { and Competitive Tourism-NECSTouR [21] }\end{array}$ & Policy makers & $\begin{array}{l}\text { (1) Limit the environmental impact of transport } \\
\text { (2) Increase the quality of life of residents } \\
\text { (3) Increase the quality of employment } \\
\text { (4) Reduce the seasonality of tourism flows } \\
\text { (5) Protect the cultural heritage } \\
\text { (6) Protect the environmental heritage } \\
\text { (7) Protect the identity of destinations } \\
\text { (8) Reduce and optimise the use of natural resources and water in particular } \\
\text { (9) Reduce and optimise energy consumption } \\
\text { (10) Reduce and manage waste }\end{array}$ & Local & Indicators \\
\hline
\end{tabular}


Table 1. Cont

\begin{tabular}{|c|c|c|c|c|}
\hline TSAI & Target Groups & Criteria & Spatial Scale & Output \\
\hline $\begin{array}{c}\text { European Charter for Sustainable Tourism in } \\
\text { Protected Areas-ECST [14] }\end{array}$ & Managers of Protected Areas & $\begin{array}{l}\text { (1) Partnership with local tourism stakeholders } \\
\text { (2) Sustainable tourism strategy and action plan } \\
\text { (3) Protecting natural and cultural heritage } \\
\text { (4) Meeting visitor needs/quality of experience } \\
\text { (5) Communication about the area } \\
\text { (6) Tourism products relating to the protected area } \\
\text { (7) Training } \\
\text { (8) Community involvement and maintaining local quality of life } \\
\text { (9) Benefits to the local economy and local community } \\
\text { (10) Managing visitor flows }\end{array}$ & Local & Indicators \\
\hline
\end{tabular}

Source: Authors' own compilation. 
The above-mentioned initiatives provide tourism actors with a range of alternative methods for operationalizing sustainability assessment. Nevertheless, the different criteria, target groups, and spatial scale of the initiatives may add an additional complexity to actors that may try to integrate more than one of the available approaches. Despite the wide application of indicator systems, in the context of measuring tourism sustainability [24,25], and a capable number of comprehensive reviews regarding the applicability of sustainability indicators under a tourism context $[10,11,26,27]$, the relevant literature review shows that there is still little evidence on how useful were the TSAIs in cases where they were used as guides for conducting sustainability assessments. More precisely, the literature includes only some evaluations focusing on a specific TSAI regarding its application in various spatial scales and types of destinations. These evaluations are conducted either by the organisations that have developed TSAIs, focusing on specific case studies, or by destinations where the sustainability assessment is realised independently from the organisations. An example of the first case is ETIS, which has implemented an evaluation of the framework in an adequate number of destinations of various geographical contexts. The most common challenges were the difficulties in engaging stakeholders and the lack of relevant data. The feedback from the destinations resulted in the updating of the list of indicators [28]. In addition, under the UNWTO Working Group on Measuring Sustainable Tourism, several pilot tests have been conducted in various destinations and country reports have been produced summarizing the perception of the systems of indicators for tourism sustainability, the feasibility of their implementation, the identification of relevant gaps, and needs for the improvement of their future application [12,29].

As for the independent evaluations, Agyeiwaah et al. [27] (p. 28) question the applicability of the UNWTO TSAI, as the issues that it covers are too exhaustive and, because of that, they claim that it is " ... a classic case of choice overload." In addition, in two reports of the Croatian Institute for Tourism [30,31] some challenges regarding the application of TSAIs are presented. More precisely, the Institute established an observatory of tourism and developed a system of indicators based on the ETIS and UNWTO TSAIs. The main difficulties of the operationalisation of the two initiatives were the lack of data, especially at the local level, the need for strong commitment of stakeholders and the lack of funding for conducting data gathering surveys.

Moreover, Dangi and Jamal [32] challenge the GSTC initiative as lacking regulatory enforcement by promoting certifications that are not mandatory. In addition, Mutana and Mukwada [33] assessed the applicability of the private sector-targeted GSTC indicators for measuring the sustainability of a route in the Drakensberg Mountains, South Africa. The authors conclude that the general applicability of the TSAI was successful. Nevertheless, the provided set of indicators did not manage to cover issues, such as the enhancement of local community's participation in tourism activities and the improvement of local stakeholders' understanding of the competitive advantages of the area. Finally, Tudorache et al. [34] and Modica et al. [25] provide some feedback for the ETIS TSAI after its application for the measurement of sustainability in the Romanian city of Brasov and the Italian tourist destination of South Sardinia, respectively. In both surveys, it is concluded that ETIS could only be considered as a general framework for guiding sustainability monitoring which should be complemented by a more operational system of indicators in order for the measurement of tourism dimensions to take place.

The present paper seeks to shed light on the challenges associated with the operationalization of tourism sustainability assessment and the implementation of the various initiatives on actual planning and management practices. To do so, the paper builds on the experiences of 14 projects focusing on Sustainable Tourism issues and funded by the Interreg-MED Programme under the 1st call of the programming period 2014-2020. The projects tackle various challenges of sustainable tourism development adopting a range of methods and tools that help them reach their targets. Among those, monitoring tourism sustainability has been stressed by the majority of the projects. Therefore, this Community of projects with different scopes and methods provides a unique opportunity to test in practice the applicability of the sustainability assessment initiatives. This common comparative assessment of TSAIs is expected to complement the -up to now- scattered evaluations of individual 
TSAIs. Moreover, the assessment will be very useful for the improvement of the available TSAIs as the responses of projects could provide a valid feedback for their applicability stemming from actual field applications. Additionally, the results of the paper could act as a useful guide for the further implementation of TSAIs in other areas and contexts. Finally, the different views of sustainability, expressed by the projects, could further enrich the ongoing academic debate around the conceptualisation of sustainable tourism development. To do so, the Horizontal Project following the Sustainable Tourism Community of projects, BleuTourMed_C3, has conducted a survey among the project representatives in order to capture their views on the overall concept of tourism sustainability assessment. Part of the survey is used in order to feed this paper.

The paper seeks to provide answers to the following research questions:

1. Do specific objectives affect perceptions of actors and stakeholders towards the concept of tourism sustainability?

2. Do different perceptions of sustainability affect the perceived Ease of Use and Usefulness towards TSA Initiatives?

3. What are the main gaps and challenges regarding the operationalization of Tourism Sustainability Assessments?

The structure of the paper is as follows; Section 2 describes the main methods and tools employed by the present paper. In Section 3 the main results of the survey are analyzed and a discussion around the three research questions of the paper is conducted. Finally, the paper ends up with the main conclusions and some future challenges regarding tourism sustainability assessment.

\section{Materials and Methods}

The methodological framework of the present paper, which is presented in Figure 1, is articulated through the three research questions that have been presented in the "Introduction" section and backed by a survey disseminated to the Community of projects. Acknowledging the heavy workload of each project participating in the survey, it was preferred to provide projects' representatives with a simple three-items survey with clear questions that would make the process a rather easy and pleasant task. Considering that a lot of criticism has been addressed to many existing TSAIs for their complexity [27], it would be rather contradictive if a survey for evaluating their applicability was based on complex questions. The 1st question of the survey was an open-ended survey item and the respondents were free to choose the terms that better describe their project's perception of sustainability. The other two questions regarded the 'ease of use' and 'usefulness' for each project. These items were close-ended and, thus, respondents were asked to choose responses from a Likert scale. The survey was forwarded to the Lead Partner of each project whilst the responses were elaborated by key project partner representatives (Work Package leaders, partners with academic background, practitioners, authorities' representatives etc.). Overall, the elaboration of the three items was a collective work of each project partnership which resulted in a single reply.

In order to extract the projects' Perception of Sustainability (Research Question 1) the project representatives were asked the following question: "Please use up to 5 keywords to describe what tourism sustainability means to your project." Through the projects' answers, they were free to shape a unique tourism sustainability concept by adjusting it on their own particular objectives and methods. Then, according to the frequency of selected key-words, a categorization of projects is extracted and a general sustainability concept by the whole community is shaped. In addition, the projects' perceived 'ease of use' and 'usefulness' towards TSA Initiatives is examined. Modica et al. [25] recognize that, for the implementation of the ETIS, the role of a destination coordinator is crucial since not all stakeholders are familiar with the complex nature of monitoring sustainability tasks. In order to do so, the coordinator should be fully aware of the strengths and weaknesses of the TSAIs in order to select the one that it would be easier adapted to the destination at stake. Taking into account that the projects of the community launched the implementation of TSAIs in many pilot areas of the Mediterranean, it is 
very interesting to see how they valued their 'ease of use' and 'usefulness' as means for understanding which TSAIs made them feel more comfortable to run the whole sustainability evaluation process. The 'ease of use' and 'usefulness' concepts have been extensively used in surveys dealing with users' acceptance and intention to use products encompassing elements of new technology [35]. In such cases, the users' intention to use a product is defined by their perceptions towards its usefulness and ease of use, but it is also affected by their socio-demographic characteristics and, sometimes, by the particular use of the product [36-38]. By adjusting these concepts to the present research, it is argued that tourism actors will show a preference on TSA initiatives for which the perception of 'usefulness' and 'ease of use' will be higher. To this end, the projects were asked to express the perceived 'usefulness' and 'ease of use' for each TSA initiative through the following questions:

"Please rank the following sustainability evaluation initiatives according to how useful they were for the development of indicators in your project"

"Please rate the following characteristics of the selected sustainability evaluation initiatives according to your project's objectives"

In order to evaluate the 'ease of use', the respondents have rated five TSAI characteristics, namely their Applicability, Provision of Guidance, Flexibility, Sensitivity to Data, and need for Stakeholders Engagement. For both questions, respondents were given a five-point Likert scale in order to rank and rate the TSA initiatives. For 'usefulness' it ranged from "Not Useful" to "Extremely Useful" while for the 'ease of use' it ranged from "Minimum Rate" to "Maximum Rate". In addition, as the acceptance and intention to use of the technology products can be affected by the socio-demographic and types of use factors, similarly, it can be argued that, the perceptions of projects regarding the TSA initiatives can also be affected by their particular objectives. This heterogeneity should be acknowledged when evaluating the usefulness of indicators because the impact of tourism varies according to the type of destination and the actors involved in the provision of the tourism offer [24,39] and, therefore, not all TSAIs may accommodate adequate measures for all impacts. Therefore, in order to capture the heterogeneity of responses, caused by the different scopes of the projects, these were asked to define the type of sustainability indicators they are dealing with (Sustainability of Destinations, Sustainability of a Product, Sustainability of a Model, and Sustainability of Tourism Actors) and the spatial scale of implementation (Local Focus, NUTS-III Focus, NUTS-II Focus, and Inter-regional Focus).

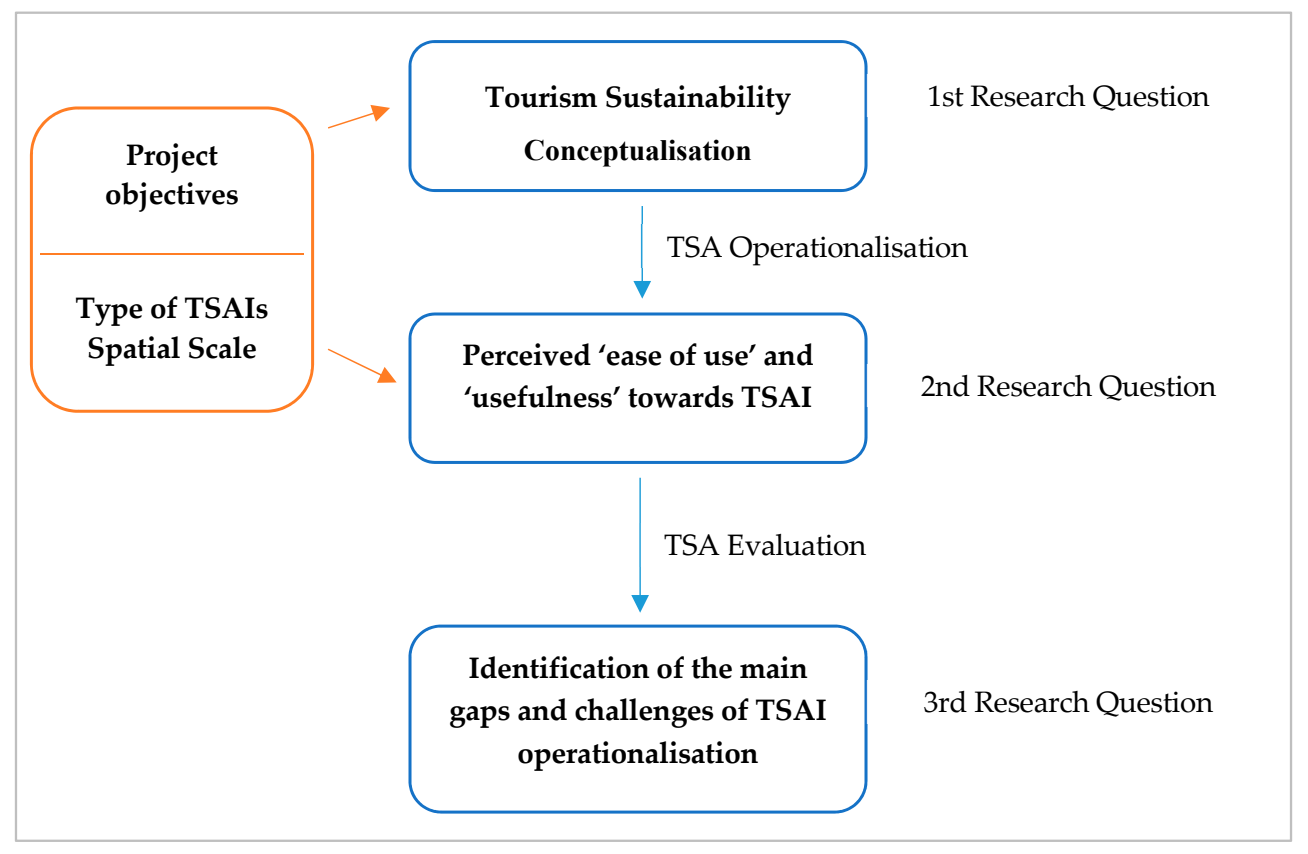

Figure 1. The methodological framework of the paper. 
Finally, as far as the Research Question 3 is concerned, the projects were asked to identify and rate the main gaps and challenges regarding the development of their own TSA frameworks. Five predefined answers were provided to respondents, namely Lack of Data, Lack of Stakeholder Cooperation, Difficulty in defining a common spatial basis, Lack of (common) time series, and Difficulty in identifying and defining thresholds, while projects were also given the choice to add any other gap and challenge that they identified through the development of their own TSA process.

\section{Results and Discussion}

\subsection{Conceptualising Tourism Sustainability within the Projects Community}

The responses of the projects regarding the five most representative keywords for tourism sustainability are presented in Table 2 . It should be noted that various terms with similar meaning were codified under the same latent category of perception and that the purpose of the categorization, presented in this paper, is limited to the triggering of discussion around sustainability perception and it, by no means, should be considered as a full representation of the projects' targets, objectives, and processes.

As can be seen from Table 2, the perceptions of sustainability do not refer only to the fulfilment of the basic targets of sustainability, but also to the paths for achieving them, such as innovation, new tourism models and exploitation of opportunities. Positioning this finding on the on-going debate around the actual meaning of the term "sustainable tourism", it could be denoted that the Community's perspective essentially adopts the rationale of previous scholars, who have recognized that, in order for tourism to be sustainable, the actual receivers of tourism services should also be taken into account [40]. This could be achieved by providing the best of experiences to visitors [41,42] and by engaging tourists in the promotion of sustainability targets [43]. In order to do so, the Community has realized that better experiences could only be provided by offering authentic local services and new and innovative tourism models, and by increasing the awareness and responsibility of tourists through relevant actions.

As it is indicated by the majority of the projects, sustainable tourism is directly linked with 'Management and Monitoring', followed by 'Preserving Local Identity', 'New Tourism Models', and 'Development of Circular and Green Economy'. The least selected keywords are 'Innovation' and 'Opportunities'.

\subsection{Evaluating Perceived 'Usefulness' and 'Ease of Use' of TSA Initiatives}

\subsubsection{Perceived 'Usefulness'}

Before presenting the results of the survey regarding the evaluation of the TSA Initiatives (TSAI), it should be noted that only ten out of 14 projects have filled in the relevant queries, since those projects are incorporating TSAIs assessments in their activities. In Figure 2, the average rating of perceived usefulness ( $\mathrm{Y}$ axis) for each TSA Initiative is plotted against the number of projects that have selected the respective TSAIs (X Axis). The two blue lines indicate the average price of each variable and, thus, four quartiles are shaped, indicating the usefulness and popularity of each initiative. As can be seen from Figure 2, ETIS has acquired the best average rating of perceived usefulness among the projects and has been considered as a guidance source during the development of TSA activities by all the projects. GSTC and UNWTO are also positioned in the upper right corner of the diagram, as they have been used by eight projects and acquire a quite high rate regarding their usefulness. Nevertheless, UNWTO has received a slightly better rating in comparison to GSTC. NECStour, which lies at the upper left corner, has been rated on average with 3.4 out of 5 for its usefulness and has been considered by seven projects. Finally, the TSAIs at the left bottom corner are ECST, INSTO, TOUERM, and OECD. Among them, OECD has been considered by the least number of projects (5) whilst TOUERM has received the lowest rating regarding its usefulness for projects' objectives (2.17/5). 
Table 2. Allocation of the Community's projects responses regarding tourism sustainability to latent concepts.

\begin{tabular}{|c|c|c|c|c|c|c|c|c|c|c|c|}
\hline \multirow[b]{2}{*}{ Project } & \multirow[b]{2}{*}{ Scope } & \multicolumn{10}{|c|}{ Perception of Tourism Sustainability } \\
\hline & & 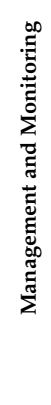 & 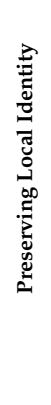 & 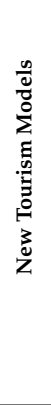 & 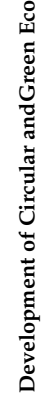 & 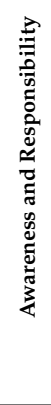 & 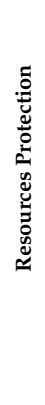 & 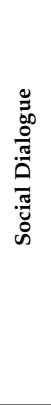 & 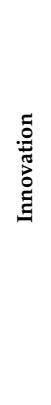 & 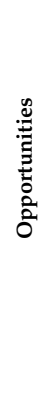 & 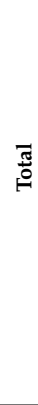 \\
\hline ALTER ECO & $\begin{array}{l}\text { Developing alternative tourist strategies in order to enhance the local } \\
\text { sustainable development of tourism by promoting Med identity }\end{array}$ & & $\mathrm{x}$ & & $\mathrm{x}$ & $\mathrm{x}$ & & & & & 3 \\
\hline BLUEISLANDS & Improving waste management and monitoring in Med islands & $\mathrm{x}$ & & & $\mathrm{x}$ & & & $\mathrm{x}$ & & & 3 \\
\hline BLUEMED & $\begin{array}{l}\text { Plan/test/coordinate Underwater Museums, Diving Parks and Knowledge } \\
\text { Awareness Centres }\end{array}$ & $\mathrm{x}$ & & & & $\mathrm{x}$ & $\mathrm{x}$ & $\mathrm{x}$ & & & 4 \\
\hline CASTWATER & Improving water management at Med coastal areas & $\mathrm{x}$ & & & $\mathrm{x}$ & $\mathrm{x}$ & $\mathrm{x}$ & & $\mathrm{x}$ & & 5 \\
\hline CO-EVOLVE & $\begin{array}{l}\text { Promoting the co-evolution of human activities and natural systems for the } \\
\text { development of sustainable coastal and maritime tourism }\end{array}$ & $\mathrm{x}$ & & & & & & & & & 1 \\
\hline CONSUME-LESS & $\begin{array}{l}\text { Building and promoting a sustainable tourism model based on the } \\
\text { "consume-less" notion }\end{array}$ & & & $\mathrm{x}$ & & $\mathrm{x}$ & & & & & 2 \\
\hline DestiMED & $\begin{array}{l}\text { Paving the way for the development of a Destination Management } \\
\text { Organization for ecotourism in protected areas }\end{array}$ & $\mathrm{x}$ & $\mathrm{x}$ & $\mathrm{x}$ & & & & & & & 3 \\
\hline EMbleMatic & $\begin{array}{l}\text { Creating and testing a new and radically different tourism offer based on the } \\
\text { features of Emblematic Med mountains }\end{array}$ & & $\mathrm{x}$ & $\mathrm{x}$ & & & $\mathrm{x}$ & & & & 3 \\
\hline MEDCYCLETOUR & Valorising EuroVelo 8 cycle tour towards more sustainable Med tourism & & $\mathrm{x}$ & $\mathrm{x}$ & & & & & & & 2 \\
\hline MEDFEST & Promoting culinary tourism based on Med heritage and diet & & $\mathrm{x}$ & $\mathrm{x}$ & $\mathrm{x}$ & & & & & & 3 \\
\hline MITOMED+ & $\begin{array}{l}\text { Improving local and regional strategies and policy actions by to increasing } \\
\text { knowledge and social dialogue }\end{array}$ & $\mathrm{x}$ & & $\mathrm{x}$ & & & & $\mathrm{x}$ & & & 3 \\
\hline ShapeTourism & $\begin{array}{l}\text { Improving Decision-Making in Tourism by enhancing the tourism } \\
\text { knowledge framework }\end{array}$ & $\mathrm{x}$ & & & $\mathrm{x}$ & $\mathrm{x}$ & $\mathrm{x}$ & & $\mathrm{x}$ & & 5 \\
\hline SIROCCO & Developing new sustainable cruise tourism models in Med regions & & & & & & & $\mathrm{x}$ & & $\mathrm{x}$ & 2 \\
\hline TOURISMED & Creating and testing new fishing tourism business model & & $\mathrm{x}$ & & $\mathrm{x}$ & & & & $\mathrm{x}$ & $\mathrm{x}$ & 4 \\
\hline Total & & 7 & 6 & 6 & 6 & 5 & 4 & 4 & 3 & 2 & \\
\hline
\end{tabular}

Source: Authors' own compilation of projects' responses. 


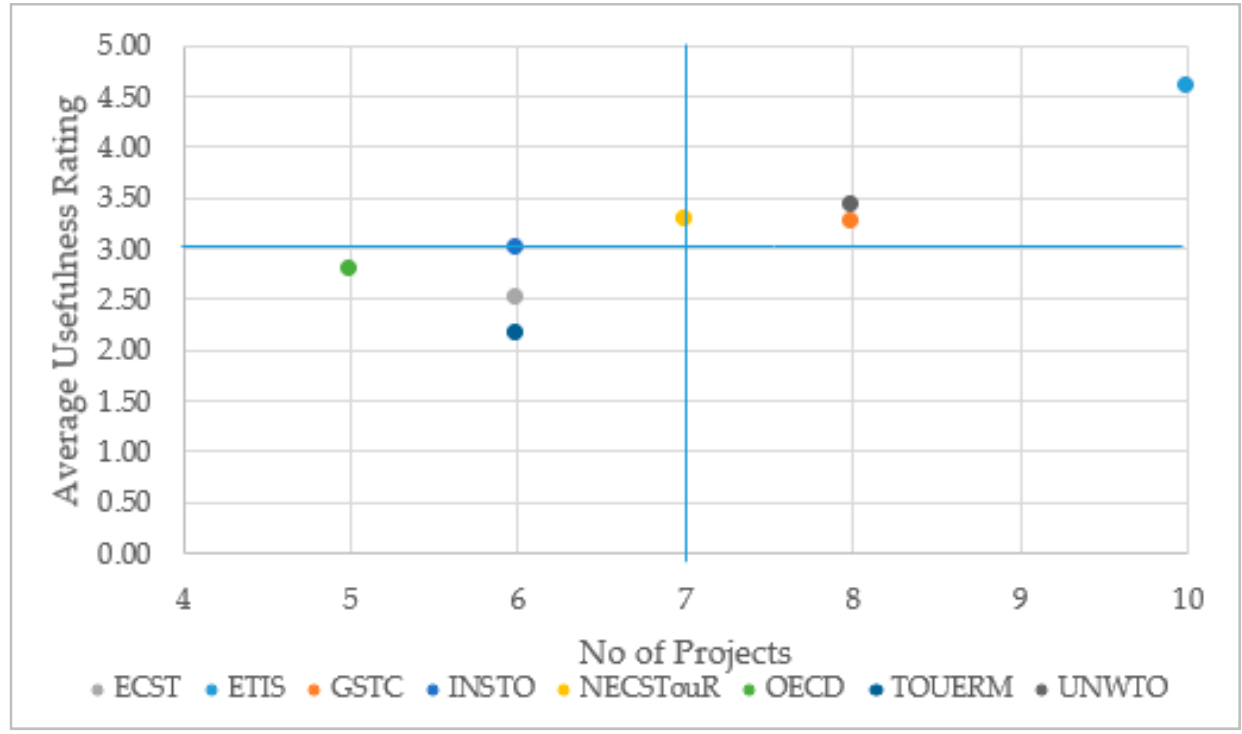

Figure 2. Average usefulness rating and reported examination for Tourism Sustainability Assessment Initiatives (TSAIs) (Since IRTS and TSA could be considered as steps of the ongoing development of UNWTO TSAI it was decided to include them as parts of the UNWTO umbrella. Therefore, the rating for UNWTO TSAI presented in the following analysis, also includes IRTS and TSA. In addition, since the INSTO observatories provide a broader range of indicators, projects were asked to rate it independently from the UNWTO TSAI).

A more detailed look about the project's perception of usefulness for every TSAI is provided in Table 3. More precisely, Table 3 presents the two or three most highly rated TSAIs for each project (the third column includes TSAIs that have equal ratings with the second most highly rated TSAI). In addition, the ratings are crosschecked with the categories of the different types of TSA employed by each project. Initially, it should be noted that four projects use TSA for assessing destinations sustainability, two for product sustainability, three for model sustainability and two for actors' sustainability. As can be seen from the data, all projects indicated that ETIS was found to be the most useful TSA for their activities. This finding denotes that ETIS provides various options for TSAs regardless of their focus. In addition, it should be considered that ETIS is a European initiative and, thus, it is closer to the context of the projects which are implemented in the Mediterranean. The second choices of projects present higher variability. Projects focusing on the sustainability of products, destinations, and actors seem to put a premium on the GSTC TSAI. This is reasonable because GSTC provides a system of indicators that could be directly adjusted on actors and their products while they also serve as a means for measuring sustainability of destinations as a whole. The other two more used TSAIs are the NECSTouR and UNWTO which have been selected by three projects. The overall selection pattern of projects focusing on models does not reveal any consensus among the projects since their second rated TSAIs are different.

In Figure 3, the influence of the projects' spatial focus on their perceived usefulness of each TSAI is examined. As can be seen, ETIS is perceived as the most useful TSAI at all spatial scales. GSTC could also be considered as the most useful TSAI for the local and inter-regional level, while UNWTO seems to be more useful for NUTS III level. Concerning NUTS II level, ETIS is followed by UNWTO and OECD with equal rating. Therefore, it can be concluded that ETIS, GSTC, and UNWTO are the most useful TSAIs for the different spatial scales. As for the other TSAIs, all of them acquire their best ratings for the NUTS II analyses, while TOUERM ratings are equal for both NUTS II and NUTS III levels. 
Table 3. Rated Tourism Sustainability Assessment Initiatives (TSAIs) per project on perceived usefulness.

\begin{tabular}{cccc}
\hline \multirow{2}{*}{ Type of TSA } & Project & \multicolumn{2}{c}{ TSAI } \\
\cline { 2 - 4 } & & 1st Rank & 2nd Rank \\
\hline \multirow{2}{*}{ Destination } & CO-EVOLVE & ETIS & GSTC \\
& MITOMED+ & ETIS & NECSTouR \\
& ShapeTourism & ETIS & INSTO, UNWTO \\
\hline Destination and Product & MEDFEST & ETIS & GSTC \\
\hline Product & DestiMED & ETIS & GSTC \\
\hline \multirow{2}{*}{ Model } & BLUEMED & ETIS & OECD, ECST \\
& TOURISMED & ETIS & All (except for ECST) \\
& ALTER ECO & ETIS & TOUERM, NECSTouR \\
\hline \multirow{2}{*}{ Actors } & SIROCCO & ETIS & GSTC \\
& CASTWATER & ETIS & UNWTO
\end{tabular}

Source: Authors' own compilation of projects' responses.

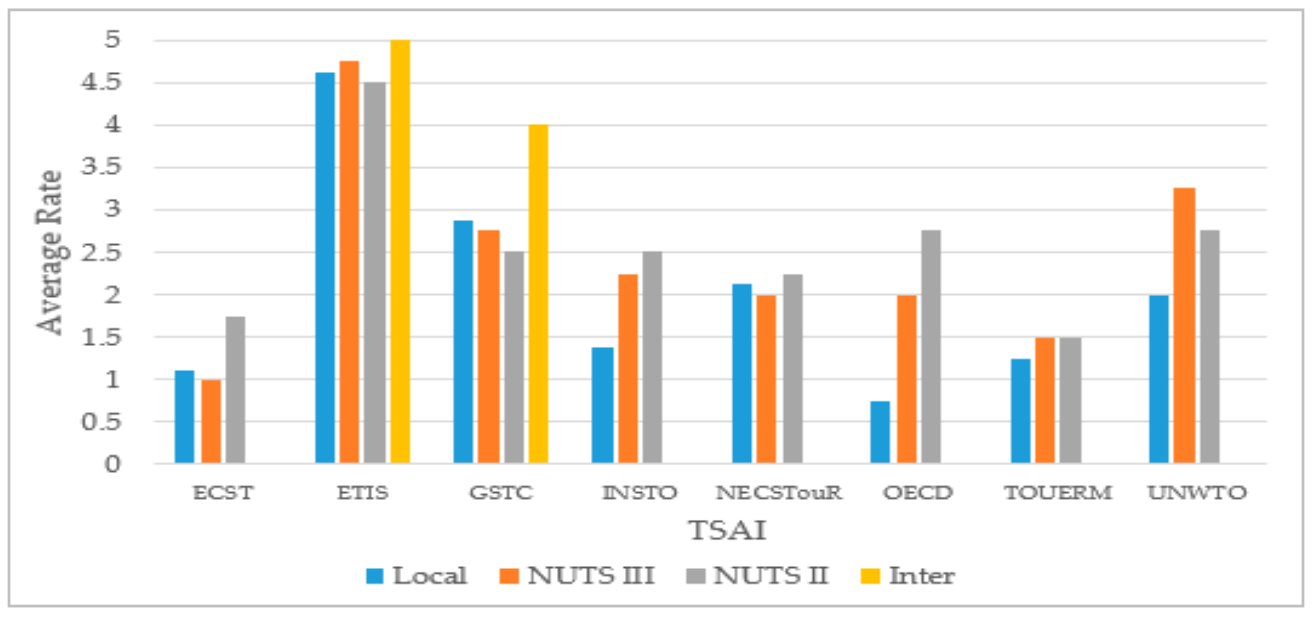

Figure 3. Tourism Sustainability Assessment Initiatives (TSAIs) usefulness rating in terms of spatial focus.

As was noted before, the perceived usefulness of projects regarding the available TSAIs may also be influenced by how they perceive tourism sustainability. In Figure 4, the average usefulness rating is presented for the five most popular perceptions of sustainability, as these are provided in Table 2 . As can be seen from the figures, ETIS is still considered the most useful tool for operationalizing all the concepts of sustainability, as it acquires high rates under all five categories. The best ratings for ETIS were provided by projects, which approach sustainability through the enhancement of 'Awareness and Responsibility (A\&R)' and the improvement of 'Management and Monitoring (M \& M)' practices. For all the other TSAIs, the ratings present high variability. NECSTouR acquires the best rating for the projects that support the improvement of 'Management and Monitoring' practices amongst all TSAIs, except the ETIS, while for the projects that put an emphasis on 'Local Identity', GSTC has received the highest rating after ETIS. GSTC is also the second most highly rated TSAI for projects that have indicated 'New Models Development' as an important element for tourism sustainability. Moreover, NECSTouR is considered as the most useful TSAI, after ETIS, for projects which put a premium on the promotion of 'Green and Circular Economy (G\& C)', and also the most highly rated TSAI-together with UNWTO—for projects supporting 'Awareness and Responsibility' for sustainable tourism. 


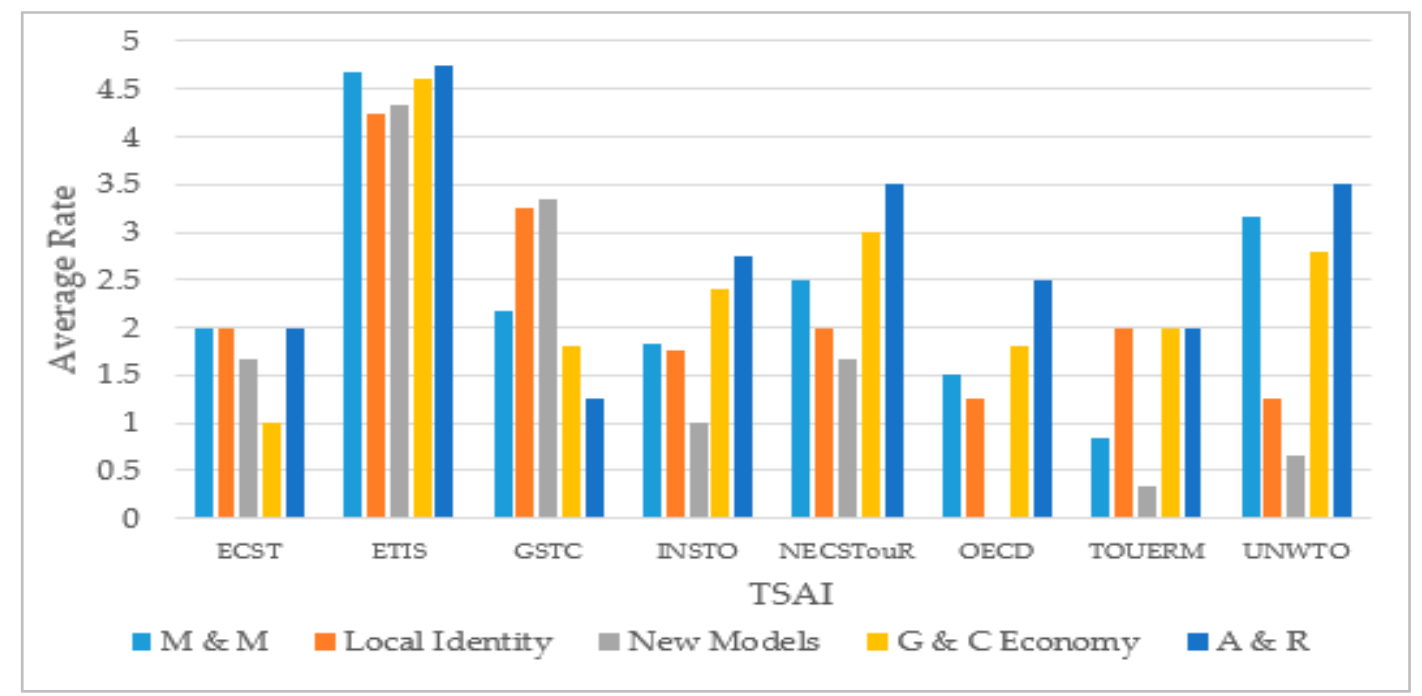

Figure 4. Tourism Sustainability Assessment Initiatives (TSAIs) usefulness rating by latent concepts of sustainability.

\subsubsection{Perceived 'Ease of Use'}

In Table 4, the ranking of the TSAIs, as extracted by their average rating under the five criteria of 'ease of use', is provided. By examining the average ranking of each TSAI, it is concluded that ETIS and GSTC are perceived as being the easiest to use initiatives, as they acquire the lowest average ranking among all the projects. On the contrary, TOUERM acquires the highest ranking, which means that its perceived ease of use by the projects has received the worst rating. ETIS has the best rank in the three criteria of 'applicability', 'guidance', and 'flexibility', ECTS acquires the highest rank on the 'sensitivity to data' criterion, meaning that it is less data demanding among all the TSAIs, while OECD is the most highly rated TSAI under the 'stakeholder engagement' criterion, as the projects have stated that its implementation is not so sensitive to stakeholders' willingness to participate. GSTC has acquired the lowest average rating under the 'applicability' criterion, NECSTouR under the 'guidance' criterion and ECST under the 'flexibility' criterion. In addition, ETIS has acquired the lowest score on the 'sensitivity to data' and 'stakeholders engagement' criteria, perhaps due to the amount of data that is required in order to feed the proposed sets of indicators and to the rather high involvement of stakeholders that is needed in order to set the thresholds or provide qualitative estimations where data is unavailable.

Table 4. Ranking of Tourism Sustainability Assessment Initiatives (TSAIs) according to their average projects rating on the basis of five criteria.

\begin{tabular}{ccccccc}
\hline TSAI & Applicability & Guidance & Flexibility & $\begin{array}{c}\text { Sensitivity } \\
\text { to Data }\end{array}$ & $\begin{array}{c}\text { Stakeholders } \\
\text { Engagement }\end{array}$ & $\begin{array}{c}\text { Average } \\
\text { Ranking }\end{array}$ \\
\hline ECST & 5 & 6 & 8 & 1 & 2 & 4.4 \\
ETIS & 1 & 1 & 1 & 8 & 8 & 3.8 \\
GSTC & 8 & 3 & 2 & 2 & 4 & 3.8 \\
INSTO & 3 & 4 & 4 & 6 & 6 & 4.6 \\
NECSTouR & 2 & 8 & 5 & 3 & 7 & 5 \\
OECD & 6 & 5 & 7 & 4 & 1 & 4.6 \\
TOUERM & 6 & 7 & 6 & 4 & 3 & 5.2 \\
UNWTO & 4 & 2 & 3 & 7 & 5 & 4.2 \\
\hline
\end{tabular}

Apart from the general perception of projects regarding the ease of use of TSAIs among the whole Community of projects, it is interesting to examine how 'ease of use' varies according to the spatial 
focus and type of TSAs developed by the projects. In Table 5, the TSAIs acquiring the highest rating (per type of TSA) regarding their ease of use is presented. As can be seen, despite the fact that ETIS has been selected as the most applicable TSAI for products and actors, NECSTouR also acquires a high rating for destinations and models together with ETIS and UNWTO. In terms of guidance, UNWTO seems to be the most user friendly for destinations and models. ETIS has been selected as providing the best guidance for products and GSTC, ISTO, and ETIS for actors. ETIS seems to be the most flexible initiative for all categories - except for destination (UNWTO). Concerning sensitivity to data, a quite high variability can be observed. GSTC seems to be less sensitive to data for products and actors. Additionally, GSTC is selected as the best option in terms of needs for stakeholders' engagement, together with ECST (products) and NECSTouR (models), while the less demanding for stakeholders' engagement are OECD (destinations) and ETIS (actors).

Table 5. Most highly rated Tourism Sustainability Assessment Initiatives (TSAIs) in terms of 'ease of use' for the four types of TSAs.

\begin{tabular}{|c|c|c|c|c|c|}
\hline TSA Focus & Applicability & Guidance & Flexibility & Sensitivity to Data & Stakeholders Engagement \\
\hline Destination & NECSTouR & UNWTO & UNWTO & Multiple & OECD \\
\hline Product & ETIS & ETIS & $\begin{array}{c}\text { GSTC } \\
\text { ETIS }\end{array}$ & GSTC & $\begin{array}{l}\text { GSTC } \\
\text { ECST }\end{array}$ \\
\hline Model & $\begin{array}{c}\text { UNWTO } \\
\text { ETIS } \\
\text { NESCTOUR }\end{array}$ & UNWTO & ETIS & NECSTouR & $\begin{array}{c}\text { GSTC } \\
\text { NECSTouR }\end{array}$ \\
\hline Actors & ETIS & $\begin{array}{c}\text { GSTC } \\
\text { INSTO } \\
\text { ETIS }\end{array}$ & ETIS & $\begin{array}{l}\text { GSTC } \\
\text { ECST }\end{array}$ & ETIS \\
\hline
\end{tabular}

Source: Authors' own compilation of projects' responses.

Accordingly, taking into account the projects' spatial focus (Table 6), ETIS seems to be the most highly rated TSAI in terms of applicability and guidance. In addition, ETIS has been also selected as the best option in terms of flexibility at the NUTS II and Inter-regional level. In terms of data sensitivity and stakeholders' engagement, ECST and OECD are mostly preferred for the local, NUTS III, and NUTS II levels, and GSTC and ETIS for the inter-regional level.

Table 6. Most highly rated Tourism Sustainability Assessment Initiatives (TSAIs) in terms of 'ease of use' for the four spatial scales of TSAs.

\begin{tabular}{cccccc}
\hline Scale & Applicability & Guidance & Flexibility & Sensitivity to Data & Stakeholders Engagement \\
\hline \multirow{2}{*}{ Local } & ETIS & ETIS & TOUERM & $\begin{array}{c}\text { OECD } \\
\text { ECST }\end{array}$ & $\begin{array}{c}\text { OECD } \\
\text { TOUERM } \\
\text { ECST }\end{array}$ \\
\hline \multirow{2}{*}{ NUTS III } & ETIS & ETIS & Multiple & $\begin{array}{c}\text { OECD } \\
\text { ECST }\end{array}$ & ECST \\
\hline \multirow{2}{*}{ NUTS II } & INSTO & ETIS & ETIS & ECST & $\begin{array}{c}\text { UNWTO } \\
\text { OECD } \\
\text { Inter-Regional }\end{array}$ \\
\cline { 2 - 4 } & GSTC & ETIS & $\begin{array}{c}\text { GSTC } \\
\text { ETIS }\end{array}$ & $\begin{array}{c}\text { GSTC } \\
\text { ETIS }\end{array}$ & $\begin{array}{c}\text { GSTC } \\
\text { ETIS }\end{array}$ \\
\hline
\end{tabular}

Source: Authors' own compilation of projects' responses.

\subsection{Evaluating Gaps and Challenges of Tourism Sustainability Assessment (TSA) Implementation}

The last step of the present methodological framework intends to examine the major gaps and challenges associated with the implementation of TSAs within the MED Sustainable Tourism Community of the projects considered in this paper. Figure 5 shows the average rating of the five predefined gaps and challenges. The lack of data seems to be the most important gap for developing and implementing TSAs. The second most rated challenge is of technical nature and has to do with the difficulty of projects in defining the thresholds of sustainability for the various selected indicators. 
The lack of stakeholder cooperation and of common time series of data acquire the same rating, while the definition of a common spatial scale seems to be the least significant gap for the projects under consideration.

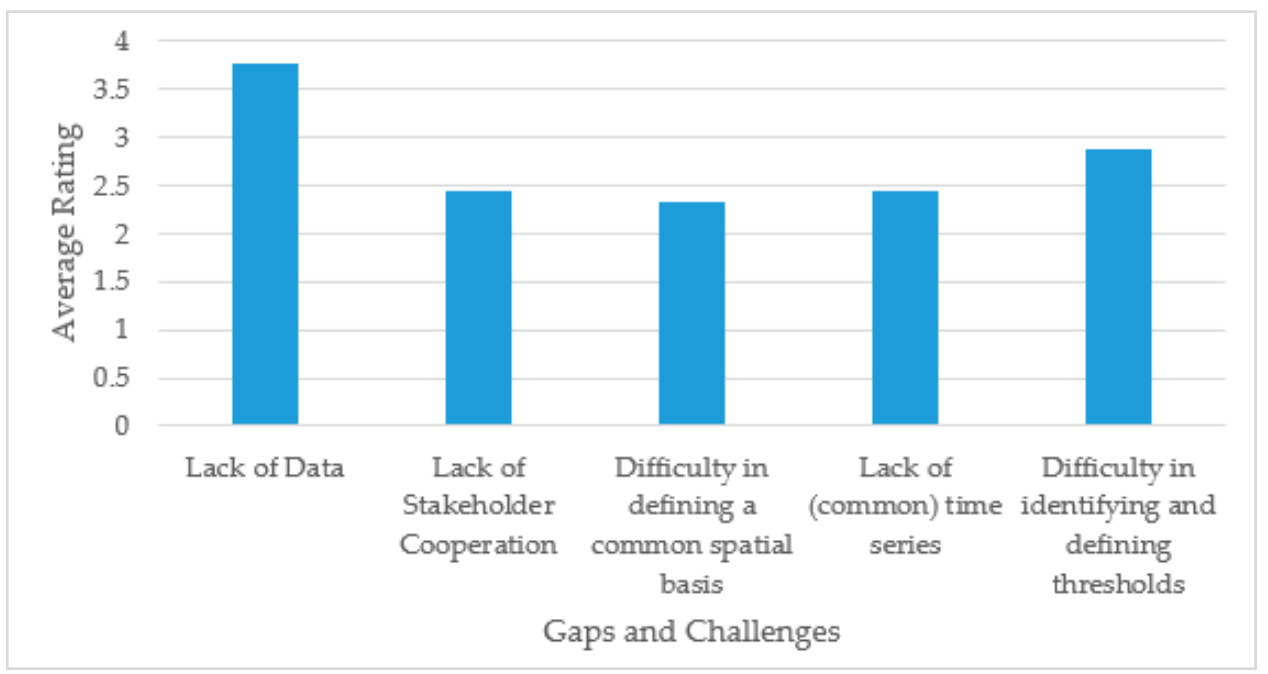

Figure 5. Average rating of gaps and challenges regarding the development of Tourism Sustainability Assessments (TSAs).

Apart from the pre-defined gaps and challenges, the projects of the Sustainable Tourism Community have also indicated some other critical remarks towards improving the development of TSAs. MITOMED+ has indicated that a conceptual homogenization of main definitions for indicators should be developed in order for projects and tourism actors to work on common theoretical grounds. This is also relevant for MEDFEST which has observed a lack of common understanding about the actual context of indicators among actors. MEDFEST has also identified the adaptability of the existing TSAIs' guidelines at the local level as a major challenge for future TSAs. This concern is also shared by CO-EVOLVE project stating that a better adaptation of TSAIs at the local level could be fulfilled only after a consensus is reached among tourism actors regarding the actual definition of the "destination" concept.

In addition, SIROCCO project, which has developed an inter-regional TSA approach, has found that data fragmentation impedes the holistic assessment of tourism sustainability among different regions. Moreover, MITOMED+ has stressed the need for employing TSAs whose structure would be as simple as possible and easily interpreted by policy makers in order to lead to concrete actions. In this direction, MITOMED+ finds that metadata and a relevant glossary should always be included in TSAs so as the actors can easily understand their results. Finally, CASTWATER project, which is exclusively focusing on water management in touristic areas, has noticed the difficulty of incorporating specialized indicators, such as those referring to water usage, in the general frameworks proposed by the existing TSAIs.

\section{Conclusions}

As interest in tourism sustainability is advancing among researchers and practitioners, the initiatives of Tourism Sustainability Assessment acquire an important role, since they pave the way for tourism authorities and actors to improve their perception of and better evaluate tourism sustainability. The present paper sheds light on the applicability of these initiatives as a means for reducing the gap between the theoretical or academic development of sustainability assessment frameworks and their application on actual case studies. The novelty of the paper mostly lies in the fact that it considered the available frameworks as products and used market analysis concepts, such as the 'usefulness' and 'ease of use', to test their acceptance by the end users, who, in the present study, were 
the projects of the Sustainable Tourism Community. As in the market of any tangible product where consumers decide to purchase it among a range of available options, similarly, tourism actors could carefully examine the best of the available TSAI options in order to incorporate them into their own objectives. But what is most important, within the market process, is the feedback that consumers send to the producers in order to improve their products and, thus, increase their marketability. To this end, the tourism actors' perceived 'usefulness' and 'ease of use' of the existing TSAIs could be a valuable input for improving the process of measuring tourism sustainability and providing a feedback for better dealing with the gaps and weaknesses associated with the available TSAIs. Therefore, with this research, which was based on a comparative evaluation of TSAIs, the gap of information between the TSAIs' developers and the end users could be reduced.

This feedback process was enriched with many interesting findings of the present survey. Initially, the projects' responses have corroborated that relying on a single TSAI for developing a TSA framework may not be the best option. This is becoming obvious by the fact that the projects of the Community have examined seven TSAIs (on average) before building their own methods. Undoubtedly, the 'usefulness' and 'ease of use' of each TSAI are decisive factors affecting the possibility to be chosen as main guidelines. This could be attributed to the complex nature of the tourism product, whose provision involves the interaction among actors from various sectors (food and beverages, fisheries, transport, etc.) and the utilization of social, natural, and cultural capital at various levels according to different types of tourism. The responses of the survey have indicated that the ETIS initiative was the most useful for the Community followed by UNWTO and GSTC. Nevertheless, the rating of the TSAIs and their induced ranking among the projects, is highly affected by the spatial focus, the type of TSA and the projects' perception of the term "sustainable tourism".

In addition, the analysis of the perceived 'ease of use' among the projects has shown that all TSAIs present advantages but also weaknesses depending on the particular aspect, under which these are examined. Although ETIS was found to be easier to apply and adjust on different contexts, the projects have identified several potential difficulties that have to do mostly with its high sensitivity to data and the high stakeholders' engagement needed for its implementation. These findings denote that, in order to develop a sound and robust TSAI, the involved actors should, firstly, conceptualize the sustainable tourism meaning according to their particular needs and objectives. Then, they should carefully examine the guidelines and the rationale of the initiatives in order to understand which characteristics better suit their needs and adjust their TSA accordingly. In addition, the examination of previous empirical applications and best practices should be taken into account along with the identification of problem-solving practices in case of gaps and challenges, such as data availability, threshold setting, and adaptability to different spatial scales.

Despite its interesting results, the present paper is not free of limitations. Although some striking differences, regarding the perceptions of the Community's projects towards the existing TSAIs, were highlighted, their validation will require a larger sample and more thorough statistical techniques, such as $t$-tests and $\chi^{2}$ tests. Moreover, a more detailed survey would be able to highlight the latent relationships of tourism sustainability perceptions and the TSAIs preferences with the use of more sophisticated analysis instruments, such as this of Structural Equation Modelling. Moreover, a larger global sample of projects and empirical applications could be selected in the future in order to build a sample which will allow for these advanced statistical analyses. In addition, the development of an evaluation system to assess the existing frameworks of indicators could shed more light on the specific needs of each type of assessment. Finally, it should be mentioned, that, although a large effort has been dedicated to include the most important TSAIs, the present work should, by no means, be considered as presenting an exhaustive list of global TSAI alternatives. 
Author Contributions: Conceptualization, S.N. and T.P.; Methodology, S.N. and T.P.; Data Curation, S.N., T.P., A.M.C. and J.R; Writing-Original Draft Preparation, S.N., A.M.C. and J.R.; Writing-Review and Editing, Y.P. and X.F.

Funding: This research was funded by Interreg-Med Programme 2014-2020.

Acknowledgments: This paper is based on the responses of representatives of 14 Modular Projects of the Sustainable Tourism Community under the Interreg-Med Programme 2014-2020.

Conflicts of Interest: The authors declare no conflict of interest.

\section{References}

1. United Nations World Tourism Organisation (UNWTO). UNWTO Tourism Highlights 2017 Edition. 2017. Available online: https://www.e-unwto.org/doi/pdf/10.18111/9789284419029 (accessed on 11 January 2018).

2. United Nations. Transforming our World: The 2030 Agenda for Sustainable Development. A/RES/70/1. 2015. Available online: http://www.un.org/ga/search/view_doc.asp?symbol=A/RES/70/1\&Lang=E (accessed on 15 January 2018).

3. Richards, G.; Hall, D. Tourism and Sustainable Community Development; Routledge: London, UK; New York, NY, USA, 2003.

4. Coccossis, H.; Mexa, A. The Challenge of Tourism Carrying Capacity Assessment: Theory and Practice; Ashgate: Aldershot, UK, 2004.

5. Swarbrooke, J. Sustainable Tourism Management; Cabi Publishing: Oxon, UK; New York, NY, USA, 1998.

6. Jovicic, D.Z. Key issues in the implementation of sustainable tourism. Curr. Issues Tour. 2014, 17, $297-302$. [CrossRef]

7. Saarinen, J. Traditions of sustainability in tourism studies. Ann. Tour. Res. 2006, 33, 1121-1140. [CrossRef]

8. Ahn, B.; Lee, B.; Shafer, C.S. Operationalizing sustainability in regional tourism planning: An application of the limits of acceptable change framework. Tour. Manag. 2002, 23, 1-15. [CrossRef]

9. Torres-Delgado, A.; Palomeque, F.L. Measuring sustainable tourism at the municipal level. Ann. Tour. Res. 2014, 49, 122-137. [CrossRef]

10. Blancas, F.J.; González, M.; Lozano-Oyola, M.; Perez, F. The assessment of sustainable tourism: Application to Spanish coastal destinations. Ecol. Indic. 2010, 10, 484-492. [CrossRef]

11. Torres-Delgado, A.; Saarinen, J. Using indicators to assess sustainable tourism development: A review. Tour. Geogr. 2014, 16, 31-47. [CrossRef]

12. United Nations World Tourism Organisation (UNWTO). Measuring Sustainable Tourism Brochure. 2018. Available online: http://cf.cdn.unwto.org/sites/all/files/docpdf/folderfactsheetweb.pdf (accessed on 11 January 2018).

13. Global Sustainable Tourism Council (GSTC). GSTC Strategic Plan 2017. 2017. Available online: https://www.gstcouncil.org/wp-content/uploads/2012/07/GSTC-Strategic-Plan-2017-web.pdf (accessed on 11 January 2018).

14. European Charter for Sustainable Tourism in Protected Areas (ECST). The Charter. 2010. Available online: https:/www.europarc.org/wp-content/uploads/2015/05/2010-European-Charter-forSustainable-Tourism-in-Protected-Areas.pdf (accessed on 15 January 2018).

15. European Commission. The European Tourism Indicator System: ETIS toolkit for sustainable destination management. 2016. Available online: https:/ec.europa.eu/docsroom/documents/21749/attachments/1/ translations/en/renditions/native (accessed on 18 January 2018).

16. United Nations World Tourism Organisation (UNWTO). Measuring Sustainable Tourism: Developing a statistical framework for sustainable tourism, Overview of the initiative. 2016. Available online: http://cf.cdn.unwto.org/sites/all/files/docpdf/mstoverviewrev1.pdf (accessed on 18 January 2018).

17. United Nations. Tourism Satellite Account: Recommended Methodological Framework 2008. 2010. Available online: https://unstats.un.org/unsd/tradeserv/tourism/manual.html (accessed on 17 January 2018).

18. United Nations. International Recommendations for Tourism Statistics. ST/ESA/STAT/SER.M/83/Rev.1. 2008. Available online: https://unstats.un.org/unsd/publication/Seriesm/SeriesM_83rev1e.pdf (accessed on 15 January 2018). 
19. Giulietti, S.; Romagosa, F.; Fons, J.; Schröder, C. Developing a “Tourism and Environment Reporting Mechanism" (TOUERM): Environmental impacts and sustainability trends of tourism in Europe. In Proceedings of the 14th Global Forum on Tourism Statistics, Venice, Italy, 23-25 November 2016.

20. Dupeyras, A.; MacCallum, N. Indicators for Measuring Competitiveness in Tourism: A Guidance Document. OECD Tourism Papers 2013. Available online: https://doi.org/10.1787/5k47t9q2t923-en (accessed on 24 July 2019).

21. Núñez, C. NECSTouR: How to Encourage Partnerships and Cooperation in Regions. 2015. Available online: http://ec.europa.eu/DocsRoom/documents/8536/attachments/1/translations/en/renditions/pdf (accessed on 15 January 2018).

22. European Commission. Communication from the Commission-Agenda for a Sustainable and Competitive European Tourism COM/2007/0621 Final. 2007. Available online: https://eur-lex.europa.eu/legal-content/EN/TXT/PDF/ ?uri=CELEX:52007DC0621\&from=EN (accessed on 15 January 2018).

23. United Nations World Tourism Organisation (UNWTO). Rules for the Operation and Management of the UNWTO International Network of Sustainable Tourism Observatories (INSTO). 2018. Available online: http://insto.unwto.org/wp-content/uploads/2017/05/INSTO_Framework_EC2016.pdf (accessed on 11 January 2018).

24. Marzo-Navarro, M.; Pedraja-Iglesias, M.; Vinzón, L. Sustainability indicators of rural tourism from the perspective of the residents. Tour. Geogr. 2015, 17, 586-602. [CrossRef]

25. Modica, P.; Capocchi, A.; Foroni, I.; Zenga, M. An Assessment of the Implementation of the European Tourism Indicator System for Sustainable Destinations in Italy. Sustainability 2018, 10, 3160. [CrossRef]

26. Ramos, T.B. Sustainability Assessment: Exploring the Frontiers and Paradigms of Indicator Approaches. Sustainability 2019, 11, 824. [CrossRef]

27. Agyeiwaah, E.; McKercher, B.; Suntikul, W. Identifying core indicators of sustainable tourism: A path forward? Tour. Manag. Perspect. 2017, 24, 26-33. [CrossRef]

28. European Commission. Presentations from the ETIS and Accessible Tourism Conference. Available online: http://ec.europa.eu/DocsRoom/documents/15362/attachments/1/translations/en/renditions/ native (accessed on 18 July 2019).

29. United Nations World Tourism Organisation (UNWTO). Pilot Studies and Country Experiences. Available online: http://statistics.unwto.org/studies_experiences (accessed on 18 July 2019).

30. Kozic, I.; Corak, S.; Marusic, Z.; Markovic, I.; Sever, I. Preliminary Report of Croatian Sustainable Tourism Observatory. Focal Area: Adriatic Croatia; Institute for Tourism: Zagreb, Croatia, 2016.

31. Markovic Vukadin, I.; Marusic, Z.; Kozic, I.; Telisman Kosuta, N. Croatian Sustainable Tourism Observatory 2018 Report Focal Area: Adriatic Croatia; Institute for Tourism: Zagreb, Croatia, 2018.

32. Dangi, T.B.; Jamal, T. An Integrated Approach to "Sustainable Community-Based Tourism". Sustainability 2016, 8, 475. [CrossRef]

33. Mutana, S.; Mukwada, G. An Exploratory Assessment of Significant Tourism Sustainability Indicators for a Montane-Based Route in the Drakensberg Mountains. Sustainability 2017, 9, 1202. [CrossRef]

34. Tudorache, D.M.; Simon, T.; Frent, C.; Musteaţă-Pavel, M. Difficulties and Challenges in Applying the European Tourism Indicators System (ETIS) for Sustainable Tourist Destinations: The Case of Braşov County in the Romanian Carpathians. Sustainability 2017, 9, 1879. [CrossRef]

35. Karahanna, E.; Straub, D.W. The psychological origins of perceived usefulness and ease-of-use. Inf. Manag. 1999, 35, 237-250. [CrossRef]

36. Lederer, A.L.; Maupin, D.J.; Sena, M.P.; Zhuang, Y. The technology acceptance model and the World Wide Web. Decis. Support Syst. 2000, 29, 269-282. [CrossRef]

37. Porter, C.E.; Donthu, N. Using the technology acceptance model to explain how attitudes determine Internet usage: The role of perceived access barriers and demographics. J. Bus. Res. 2006, 59, 999-1007. [CrossRef]

38. Zhao, J.; Fang, S.; Jin, P. Modeling and Quantifying User Acceptance of Personalized Business Modes Based on TAM, Trust and Attitude. Sustainability 2018, 10, 356. [CrossRef]

39. Nunkoo, R.; Ramkissoon, H. Developing a community support model for tourism. Ann. Tour. Res. 2011, 38, 964-988. [CrossRef]

40. Liu, Z. Sustainable tourism development: A critique. J. Sustain. Tour. 2003, 11, 459-475. [CrossRef] 
41. Bramwell, B.; Lane, B. Sustainable tourism: An evolving global approach. J. Sustain. Tour. 1993, 1, 1-5. [CrossRef]

42. Throsby, D. Tourism, heritage and cultural sustainability: Three 'golden rules'. In Cultural TOUrism and Sustainable Local Development; Girard, L.F., Nijkamp, P., Eds.; Ashgate Publishing: Surrey, UK; Burrlington, VT, USA, 2009; pp. 13-30.

43. Caruana, R.; Glozer, S.; Crane, A.; McCabe, S. Tourists' accounts of responsible tourism. Ann. Tour. Res. 2014, 46, 115-129. [CrossRef]

(C) 2019 by the authors. Licensee MDPI, Basel, Switzerland. This article is an open access article distributed under the terms and conditions of the Creative Commons Attribution (CC BY) license (http://creativecommons.org/licenses/by/4.0/). 